non-pharmacological advice, and assessing the side effects of drugs.

\section{Ambulatory blood pressure monitoring}

The role of 24 hour ambulatory blood pressure monitoring is being evaluated. ${ }^{25}$ At present it has little place in routine management, largely because of costs and the absence of long term prognostic data. It is used in specialist centres in the assessment of borderline hypertension and "white coat" hypertension. ${ }^{26}{ }^{27}$

\section{Stopping treatment}

Patients (usually with mild hypertension) whose blood pressure is consistently within the target range and in whom there is no evidence of target organ damage may have their doses of antihypertensive drugs reduced with careful monitoring. In some patients drug treatment may be withdrawn. Nonpharmacological measures should be continued indefinitely. Subsequent regular long term blood pressure monitoring is mandatory.

1 Swales JD, Ramsay LE, Coope JR, Pocock SJ, Robertson JIS, Sever PS, et al. Treating mild hypertension. BMF 1989;298:694-8.

Joint National Committee. 1988 Report of the JNC on detection, evaluation and treatment of high blood pressure. Arch Intern Med 1988;148:1023-38.

3 Guidelines Sub-Committee. 1989 Guidelines for the management of mild hypertension: memorandum from a WHO/ISH meeting. I Hypenension 1989;7:689-93.

4 SHEP Cooperative Research Group. Prevention of stroke by antihypertensive drug treatment in older persons with isolated systolic hypertension. $\mathscr{F} A M A$ 1991;265:255-64

5 Dahlof B, Lindholm LH, Hansson L, Schersten B, Ekbom T, Wester PO. Morbidity and mortality in the Swedish trial in old patients with hypertenMorbidity and mortality in the Swedish trial in old par

6 Medical Research Council Working Party. MRC trial of treatment of hypertension in older adults: principal results. $B M \mathcal{F}$ 1992;304:405-12.

7 Petrie JC, O'Brien ET, Littler WA, de Swiet M, Padfield PL, Dillon MJ. British Hypertension Society recommendations on blood pressure measurement. BMI 1986;293:611-5

8 Treatment of Mild Hypertension Research Group. The treatment of mild hypertension study: a randomised, placebo-controlled trial of nutritional- hygienic regimen along with various drug monotherapies. Arch Intern Med 1991;151:1413-23.

9 Medical Research Council Working Party. MRC trial of treatment of mild hypertension: principal results. $B M \mathcal{F}$ 1985;291:97-104.

10 Hamilton M, Thompson EN, Wiesniewski TKM. The role of blood pressure control in preventing complications of hypertension. Lancet 1964;i:235-8.

11 Veterans Administration Cooperative Study Group on Antihypertensive Agents. Effects of treatment on morbidity in hypertension; results in patients with diastolic blood pressure averaging 115 through $129 \mathrm{~mm} \mathrm{Hg}$. fAMA 1967;202:1028-34.

12 Veterans Administration Cooperative Study Group on Antihypertensive Agents. Effects of treatment on morbidity in hypertension. II. Results of patients with diastolic blood pressure averaging 90 through $114 \mathrm{~mm} \mathrm{Hg}$. IAMA 1970;213:1143-51

13 Stamler J, Neaton JD, Wentworth DN. Blood pressure (systolic and diastolic) and risk of fatal coronary heart disease. Hypertension 1989;13(suppl 1):2-12.

14 MacMahon S, Peto R, Cutler J, Collins R, Sorlie P, Neaton J, et al. Blood pressure, stroke and coronary heart disease. Part 1. Prolonged differences in blood pressure: prospective observational studies corrected for the regresblood pressure: prospective observational

15 British Hyperlipidaemia Research Association. Detection and management of blood lipid disorders. Current Science. London:1990:5-8.

16 British Hyperlipidaemia Research Association. Strategies for reducing coronary heart disease and desirable limits for blood lipid concentrations: guidelines of the British Hyperlipidaemia Association. BMF 1987;295: $1245-6$.

17 Taskforce on Prevention of Coronary Heart Disease. Scientific background and new clinical guidelines. Nutrition, Metabolism and Cardiovascular Diseases 1992;2:113-54.

18 Fletcher AE, Bulpitt CJ. How far should blood pressure be lowered? $N$ Engl f Med 1992;326:251-4.

19 Cruickshank JM, Thorpe JM, Zacharias FJ. Benefits and potential harm of lowering high blood pressure. Lancet 1987;i:581-4.

20 Fletcher A, Beevers DG, Bulpitt CJ, Butler A, Coles EC, Hunt D. The relationship between a low treated blood pressure and IHD mortality. A report from the DHSS hypertension care computing project (DHCCP). report from the DHSS hyp

21 Cruickshank JM. Coronary flow reserve and the J-curve relation between diastolic blood pressure and myocardial infarction. BMF 1988;297:1227-30.

22 Rosman J, Weidmann P, Ferrari P. Antihypertensive drugs and serum lipoproteins. Fournal of Drug Development 1990;3(suppl 1):129-39.

23 Fletcher AE, Bulpitt CJ, Chase DM, Collins WCJ, Furberg CD, Goggin TK, et al. Quality of life with three antihypertensive treatments-cilazapril, atenolol, nifedipine. Hypentension 1993;19:499-507.

24 Hjemadahl P, Wiklund IK. Quality of life on antihypertensive therapy. Scientific end-point or marketing exercise? f Hypertension 1992;10:1437-46.

25 Pickering TG, O'Brien E. Second international consensus meeting on 24 hour ambulatory blood pressure measurement: consensus and conclusions. f Hypertension 1991;9(suppl 8):S2-6.

26 Pickering TG. Can ambulatory blood pressure monitoring improve the diagnosis of mild hypertension? f Hypertension 1990;8(suppl 6):S43-7.

27 O'Brien E, Cox J, O'Malley K. The role of 24 hour ambulatory blood pressure measurement in clinical practice. 7 Hypertension $1991 ; 9$ (suppl 8):S63-5.

(Accepted 28 fanuary 1993)

\title{
Is the money following the clients with learning disabilities?
}

\author{
Gyles R Glover, Jenifer Rohde, Richard D T Farmer
}

For the past decade patients with learning disabilities living in long stay mental handicap hospitals have been resettled in the community. Local authorities have also taken on the care of new patients who would once have been long stay residents. The imperfect data that are available suggest that in England about half the residents in mental handicap hospitals in 1981 are now the responsibility of local authorities; the figures for Wales and Northern Ireland are $38 \%$ and $33 \%$. Data on revenue suggest that the savings to the health service are much less -perhaps $9 \%$ in Northern Ireland and 3.6\% in England, although there have also been capital gains through the sale of hospitals. Existing methods of transferring money from health to local authoritiesjoint finance and "dowries" for individual patients $\rightarrow$ do not seem adequately to have compensated local authorities. Moreover, as patients still to be transferred are more severely disabled local authorities will require larger sums-about $£ 26000$ per patient per year plus $£ 39200$ in capital. If the government chooses not to transfer these resources from health authorities it will be switching funds away from learning disabled people to other care groups.

Department of Health figures show that over the past decade the number of residents of hospitals for people with learning disabilities has substantially declined. This reflects a progressive transfer of responsibility for the care of these people from health authorities to local authority social services departments. This transfer has been government policy since 1959.' Desirable as such a transfer might be, if it is to work the money for the care of these clients needs to follow them. We look here at some new information about how much of the burden of care has shifted in the past decade and how much of the funding has followed.

Two new sources of information have become available. Detailed evidence about the City of Westminster and the Royal Borough of Kensington and Chelsea has been collated by the academic department of public health and epidemiology at Charing Cross and Westminster Medical School, where two of us (RDTF and JR) have recently studied the register of the learning disabled people of the two boroughs covering the past eight years. National data come from responses to a series of written questions to the four secretaries of state with responsibility for the British health service, put down in the last weeks of the old parliament by the then Liberal democrat health spokesperson, Charles Kennedy MP. ${ }^{2}$

The information is incomplete and comes in an imperfect format, and we have had to make several assumptions in analysing it. Nevertheless, in view of
Correspondence to:

\section{Academic Departm
Public Health and \\ Public Health and
Epidemiology, Charing
Cross and Westminter Medical Sc lecturer Jenifer Ro
organiser
Richard D \\ Richard D T Farmer, \\ Gyles R Glover, senior}

vOLUME 306

0 APRIL 1993 
the importance of the subject to a particularly disabled group we thought that the present, imperfect analysis was worth presenting.

\section{How many people have been transferred?}

By 1991 the number of inpatients in mental handicap units in England had dropped to 22000 , a fall of just under half the 1981 figure. In Wales and Northern Ireland the decline was less, $38 \%$ and $32 \%$ respectively (table I). Some of these hospital residents had died, and others had been resettled in community based accommodation.

There is no evidence that the overall number of cases of learning disability per thousand population declined over this period. Fryers suggests that there was a rise in the number of new cases in the early 1960s with a fall to previous levels in the early $1970 \mathrm{~s} .{ }^{3}$ This would give an increased adult caseload in the forthcoming decade. In addition the life expectancy of Down's syndrome sufferers is known to have increased. It is thus reasonable to suppose that each person with learning disability dying in hospital has been succeeded by at least one new person, no less disabled, who has not entered long stay hospital care. Indeed, the assumption of one successor is probably an underestimate.

The Kensington and Westminster figures show an annual death rate of $2.4 \%$ for residents of mental handicap hospitals. Applied to the figures presented, which cover the 9 years 3 months from December 1981 to March 1991, this would give a total decline in the inpatient population of $20 \cdot 1 \%$. (The figure is slightly less than $9.25 \times 2.4$ since a steady percentage decline produces a declining baseline.) Given the annual numbers of residents of mental handicap hospitals in England, Wales, and Northern Ireland, this suggests annual average resettlement rates of about $4 \cdot 7 \%$, $2 \cdot 75 \%$, and $1 \cdot 75 \%$ respectively. Table I shows estimated numbers of deaths and resettlements in 1981-90 in each part of the United Kingdom based on these figures.

TABLE I-Numbers of residents in mental handicap hospitals, 1981 and 1990, and implied net departures from hospital over the decade with estimated numbers of deaths and resettlements

\begin{tabular}{lrrr}
\hline & England & Wales & N Ireland \\
\hline No of residents in: & & & \\
1981 & 43019 & 2153 & 1737 \\
1990 & 22117 & 1335 & 1185 \\
Implied No of net departures: & 20902 & 818 & 552 \\
Deaths & 7041 & 382 & 320 \\
Resettlements & 13861 & 436 & 232 \\
\hline
\end{tabular}

Such a projection assumes that the death rate among residents of mental handicap hospitals from Kensington and Westminster broadly reflects the national picture. There are no data available to support or contradict this assumption. The individuals concerned are mostly people who have lived in hospital for several decades. Thus the institutional framework of the hospitals would probably minimise other factors that might affect their life expectancy. In this respect there is no reason to believe that the hospitals serving Kensington and Westminster are exceptional. It is possible that admissions to mental handicap hospitals may have declined earlier in this area than in other parts of Britain, giving rise to a current patient group which is on average older than the national patient group. This would be expected to give them a higher death rate. However, this issue is important only to the question of how much of the transfer of care has happened by death and succession as opposed to resettlement. It does not affect the estimate of the scale of the overall transfer.

\section{How much has the health service saved?}

Of the government departments questioned, only the Northern Ireland and Welsh offices produced figures on the level of revenue spending in mental handicap hospitals over the period. The figures for Northern Ireland illustrate that savings have not been in proportion to the reduction in the numbers of patients. Between 1981 and 1990 the number of inpatients fell by $32 \%$ from 1737 to 1185 . The total revenue budget, however, fell by only $9 \%$ from $£ 23.4 \mathrm{~m}$ to $£ 21.3 \mathrm{~m}$, representing an increase in the annual cost per resident of $33 \%$ from $£ 13500$ per person to $£ 17900$ per person. (All figures at constant 1991 prices.)

Department of Health figures given to the House of $\frac{\bar{O}}{\bar{D}}$ Commons Social Services Select Committee indicate $\vec{\nabla}$ that for England the savings have been even less. ${ }^{4}$ 을 Between 1979 and 1989 the number of inpatients fell क by $40 \%$ from 45419 to 27700 . This was accompanied $\vec{\circ}$ by a fall in revenue spending (at $1988-9$ prices) of only $\overrightarrow{\vec{H}}$ $£ 22 \cdot 2 \mathrm{~m}$ or $3 \cdot 6 \%$, from $£ 608 \cdot 3 \mathrm{~m}$ to $£ 586 \cdot 1 \mathrm{~m}$.

There are two likely explanations for the failure to $\frac{\partial}{D}$ achieve substantial savings by this stage. Firstly, many 3 . of the costs of running a hospital cannot be recouped $\dot{\omega}^{\circ}$ until the whole hospital is closed (the "fixed" costs). Secondly, the first patients discharged were probably $\infty$ the least disabled, ${ }^{5}$ so it would not have been possible to $\omega$ make proportionate reductions in nursing staff.

Information about the scale of capital resources liberated was more readily available and is summarised in table II. The parliamentary answers giving these $\overrightarrow{0}$ figures indicated differences in the method of alloca- $D$ tion of these resources. In Wales all the proceeds were said to have been used for the same care group. In Scotland one fifth went into the central Scottish health service capital programme and the remainder to the health board concerned. Some boards chose to use these funds for projects for people with learning disabilities; others did not.

\section{Transfer of resources}

Money has been transferred from the health service to local authorities in two ways-through joint finance and dowries. Joint finance money was first allocated in the late 1970 s as "pump priming" for new community care projects. Some, though it is not clear exactly how much, has been used for work with learning disabled people. However, for each project this revenue subsidy is of limited duration, usually only three years. At the end of that time the local authority is expected to take $\frac{0}{3}$ up the funding commitment from its general funds.

In the middle 1980 s the mechanism of "dowry" 을 payments was developed. Capital dowries were single N payments made at the time individuals were dis- $D$ charged into the care of the local authority. Revenue dowries were initially intended to be paid annually thereafter with no limit of time: they would continue N after the death of the discharged person and thus would $\stackrel{\omega}{\sigma}$ recognise that natural replacement was occurring. An early North West Thames region policy statement on dowry arrangements concluded that the amount $\stackrel{\mathcal{D}}{\rightarrow}$ should be $£ 20000$-30000 capital plus an average of $£ 11000$ a year for each transferred patient (more or less depending on the degree of disability). ${ }^{6}$ At 1991 prices $\stackrel{\mathbb{\Omega}}{\Omega}$ this would equate to $£ 26100-39200$ capital plus $\vec{D}$ $£ 14400$ revenue. The revenue dowry figure assumed that the individuals would be housed in homes provided by the independent sector and thus be able to 8 draw on substantial social security payments such as the board and lodging allowance. The dowry payments

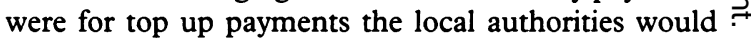
have to make to cover the shortfall between the benefit and the real cost and to fund the additional local facilities, such as day centres, which would be needed.

For new transfers from patients still in hospital, 


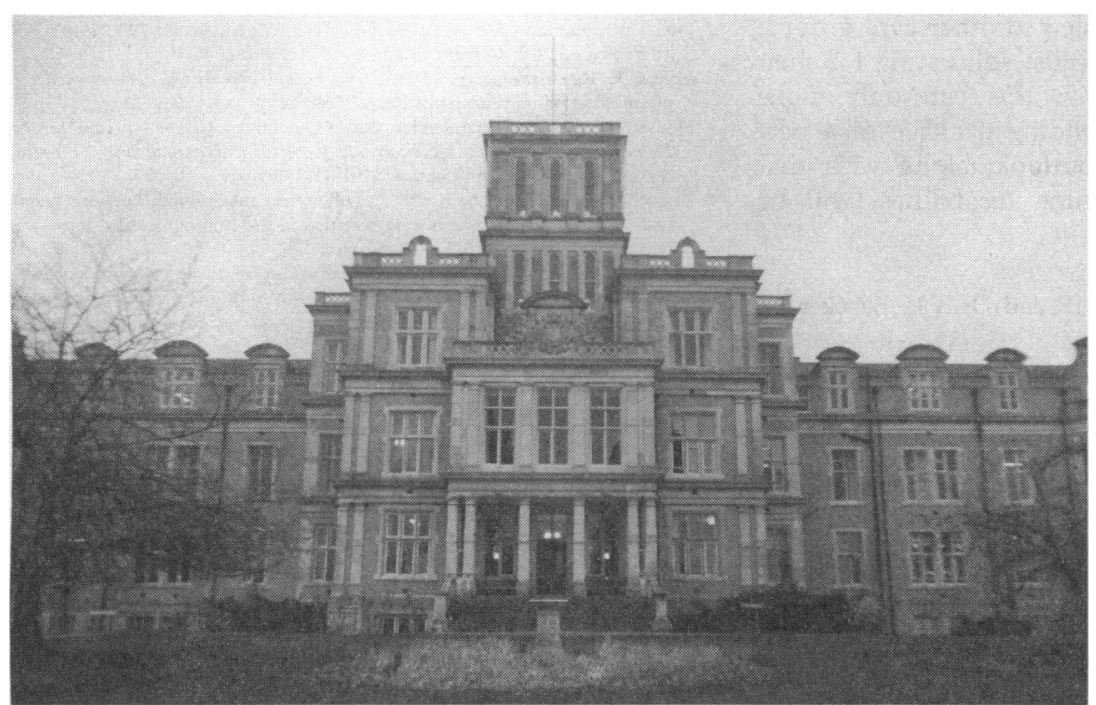

The NHS has retained much of the money it has saved in resettling patients from long stay mental handicap hospitals into the community total gain to local authority budgets would have been about $£ 300 \mathrm{~m}$. The transfer has not achieved a proportionate saving to the health service, costs for England having reduced by only around $£ 22 \mathrm{~m}$. In the most recent year for which figures are available, local authorities received just over $£ 12 \mathrm{~m}$ in the form of dowry and a further, probably small, amount as time limited joint finance.

It used to be argued that care in the community was cheaper than care in hospitals. Recent research from the personal social services research unit makes it clear that this is not the case for patients with learning disabilities. ${ }^{8}$ Indeed, the cost of providing community based care is about $17 \%$ higher than that of the old hospital services.

Transfer of the remainder of the hospital residents is likely to make greater financial demands on the receiving authorities as the group so far resettled appears to have been predominantly the younger, less disabled members of the original hospital population.

These conclusions must be tentative because the data sources are poorly developed. The difficulty ministers had in answering comparatively straightforward questions is eloquent testimony to the inadequacy of current systems. Within the health service the new Körner systems go some way to answering this problem, but producing data that straddle health and social services authorities, essential to planning for this care group, remains difficult.

It is a great tribute to local government that it has achieved so much diversion of funds to this new area of responsibility, particularly as local authority finance is currently characterised by tight constraints on total budgets. Authorities are unlikely to be able to divert further substantial resources to take up the care of people with learning disabilities. What new money can be found in the near future is likely to be committed to picking up the funding of existing projects currently receiving joint finance.

If the government wants transfer of care to proceed local authorities must be allowed the resources to meet the cost. This funding should be considered in two parts: that which relates to the part of the caseload already transferred and that which relates to the remainder

The transfer of revenue to local authorities is only around half what has actually been saved. This dowry money relates to only a few of the resettled patients. With regard to the element of the caseload transferred through death and succession there has been no transfer, even of those resources which have already been liberated.

The multiple disabilities of the remaining hospital residents suggest that the new spending demands they will make on local authorities will substantially exceed the cost of the first half of the transfer. A figure of around $£ 575 \mathrm{~m}$ (or $£ 26000$ - the middle of the current North West Thames range-for each remaining patient) would seem to be realistic for England. This should be funded as a new element in local authorities' standard spending assessment, although the government might wish in the first instance to ring fence it. Capital resources will also be needed. These could be made available through local authorities or through the Housing Corporation. The uprated North West Thames estimate of $£ 39200$ of capital per severely disabled patient would suggest a sum of about $f 867 \mathrm{~m}$ for the whole of England, phased over the remainder of the resettlement period, which could be a further decade or more.

In the longer term all the revenue element should be saved by health authorities, and the old hospital sites will be available for sale. The government may choose to leave these resources with the health service. If it does this would constitute a choice to switch resources 
away from the learning disabled to other care groups. For parents in their 70 s and 80 s, still caring for their often very disabled offspring, this can only make matters worse. Without a funding package of a new order of magnitude, their outlook, along with that of school leavers with learning disabilities, will be increasingly bleak.

We thank Charles Kennedy MP and Dr Tad Baecker for their help in this study.

1 DHSS (1971). Better services for the mentally handicapped. (para 51) London: HMSO.
2 House of Commons. Hansard 1992;5 Feb:col 207; 6 Feb:cols 280,289-92,257; 10 Feb:cols 377-9; 14 Feb:cols 653-6

Fryers T. The epidemiology of severe intellectual impaimnent. The dynamics of prevalence. London: Academic Press, 1984.

4 House of Commons Social Services Select Committee Community cars. Services a for people with a mental handicap and people euih

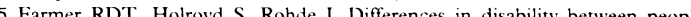
wer RDT, Holroyd S, Rohde J. Differences in disability between peop with mental handicaps who were resettled in

6 Kenny DJ. Health services for mentally handicapped people, a policy statement. I ondon: North West Thames Regional Health Authority, January 1986

7 Audit Commission. Community care: managing the cascade of change. London HMSO, 1992

8 Knapp M, Cambridge P, Thomason C, Beecham J, Allen C, Darton R. Care in the community: challenge and demonstration. Canterbury: Personal Social Services Research Unit, University of Kent, 1992.

\title{
Countdown to Community Care
}

\section{Helping disabled people-the user's view}

\author{
Peter Swain
}

This is one of a series of articles looking at the changes to community care
The main needs for most people with physical disabilities are housing and help with daily living. Thus, many of them will find the new emphasis on social aspects of community care particularly relevant. Peter Swain is a disabled man who leads a project in east Devon which ensures that disabled people have a voice in helping to shape the services they need. In this article he explains how the project, Living Options East Devon, works and how the new legislation for community care might affect disabled people.

All disabled people would get a good deal if unlimited funding were available for community care. They would have individual assessments of need to identify care packages and equipment required for independent living. Care managers would have the satisfaction of working in a system that allowed them to solve problems and use the skills they had learnt during training. Until recently, the strong Swedish and Danish social welfare systems offered such services with few cost constraints.

But our new world of community care is cash limited. Clearly, priorities will have to be set and only the most pressing needs will be met. People with physical disabilities have certain key priorities for care (see box), the most basic of which is somewhere to live.

\section{Special housing}

Without suitable housing, community care for disabled people is doomed to failure. But the government's initial publications on the reforms did not mention housing. Subsequent documents highlighted the need for and lack of adequate "special needs" provision. New building programmes for disabled people have been reduced substantially ${ }^{2}$ and the availability of suitable rented accommodation was decimated in the 1980 s by the policy that gave council tenants the right to buy their homes.

The lack of housing is lamentable, given the growing numbers of people who have long life expectancy but severe disability after surviving accidents. There are also many more young people who now hope to live independently in the community, rather than in institutions or their parents' homes, after passing through special education. Expectations are growing constantly and packages of care must begin to match them.

\section{Care packages}

There is nothing new about care packages. They have been used for years by a few disabled people, but often at huge cost. ${ }^{3}$ The concept of care management is not new, either. A similar job has been done for years by good home care organisers who know their patches and can mobilise swiftly a range of services to meet a variety of needs. The reforms simply identify and formalise this role.

Clearly identified care managers could make the process of referral relatively straightforward, predictable, and quick. Effective referral should take into account clients' views on services, and this will depend on good, up to date information on what is available so that clients can make informed choices. Social services departments must ensure that such information is readily available. They must also decide on realistic minimum standards and time intervals for responding to referrals, setting up assessments, and initiating packages of care.

Assessment should be a joint exercise, with disabled people and, when appropriate, their carers participating. They will be in the best position to ensure that their other essential needs-access, mobility, and opportunity-are provided for along with housing and domiciliary support. These "value added" factors open the way to further and higher education, employment, personal relationships, and all those other things that contribute to an acceptable quality of life. Ignoring these factors during assessment would reduce considerably the potential benefits of the new system and would leave many disabled people unfulfilled and unnecessarily limited.

Thus, good holistic care management could help the overall development of disabled people's potential. Some people might want to act as their own care managers, although they would probably need training to acquire the skills needed to employ and organise teams of care staff.

As well as providing for clients' basic needs and potentials, care packages must be responsive, flexible, and reliable (see case study 1). Whenever possible a single agency should provide the bulk of care. This approach is less intrusive for clients, cheaper to provide, and less bureaucratic to administer than a multiagency package. ${ }^{4}$ When many services are provided, they must be coordinated properly-having staff stacking up at the door waiting to do the next job is almost as frustrating as having no one turn up.

Finally, what about the frustrations of the care
Devon, Ashclyst Centre Whipton, Exeter EX1 3 r 